\title{
Simulation models for implementation of lean production concepts in earthmoving and paving
}

\section{Levy Sarmento de Matos ${ }^{1}$, Bruno de Athayde Prata ${ }^{2}$, Ernesto Ferreira Nobre Júnior ${ }^{3}$, Francisco Heber Lacerda de Oliveira ${ }^{4}$}

${ }^{1}$ Universidade Federal do Ceará, levysarmentodematos@hotmail.com

2Universidade Federal do Ceará, baprata@ufc.br

3Universidade Federal do Ceará, nobre@ufc.br

4Universidade Federal do Ceará, heber@det.ufc.br

\section{Recebido:}

18 de junho de 2016

Aceito para publicação:

12 de janeiro de 2018

Publicado:

30 de abril de 2018

Editor de área:

Kamilla Vanconcelos

\section{Keywords:}

Lean construction,

Decision support systems,

Earthmoving,

Paving.

\section{Palavras-chaves:}

Construção enxuta,

Sistema de suporte à decisão,

Terraplenagem,

Pavimentação.

DOI:10.14295/transportes.v26i1.1405

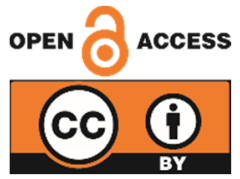

\begin{abstract}
Studies show that, despite the resistance of professionals to new modes of production, the application of Lean Construction philosophy improves the operations productivity, reducing costs and improving the quality of the final product. However, methodologies which evaluate the impacts of the implementation of this philosophy to road construction operations are scarce. This study aims to verify the improvements that the application of the Lean Construction Philosophy can bring to earthwork and paving operations in a matter of execution time and overall cost by developing a computational model and simulating different application scenarios and checking their benefits through a comparison of activity durations and equipment costs. After model development and data analysis, it was found that the models that incorporated the guidelines of the Lean philosophy got faster (up to $30 \%$ reduction in runtime) and cheaper (reduction of up to $28 \%$ on cost) results in terms of use of equipment's.
\end{abstract}

\section{RESUMO}

Estudos mostram que, apesar da resistência de profissionais a novos modos de produção, a aplicação da filosofia Construção Enxuta melhora a produtividade das operações, reduzindo custos e melhorando a qualidade do produto final. No entanto, metodologias que avaliam os impactos da implementação desta filosofia para a construção de estradas são escassas. Este estudo tem como objetivo verificar as melhorias que a aplicação da Filosofia Construção Enxuta pode trazer para terraplenagem e operações de pavimentação em matéria de tempo de execução e custo total pelo desenvolvimento de um modelo computacional e simulação de diferentes cenários de aplicação e verificação de seus benefícios através de uma comparação de duração de atividades e custos de equipamentos. Após o desenvolvimento do modelo e análise dos dados, descobriu-se que os modelos que incorporavam as diretrizes da filosofia Enxuta ficaram mais rápidos (até $30 \%$ de redução na execução) e mais baratas (redução de até $28 \%$ nos custos), resultados em termos de uso de equipamentos.

\section{INTRODUCTION}

Earthmoving and paving services are related to the movement of thousands of tons of materials, using a great amount of heavy machines and requiring a special attention from construction companies and contractors. Therefore, the rationalization in the selection of equipment, as well as the fleet sizing, are actions of great importance, enabling the reduction of the related costs and times.

Modeling a system allows a better comprehension of the real process, enabling the planners to forecast their behavior and to determine interventions for the mitigation of failures and losses. The operation of heavy machines in earthmoving and paving services can be represented 
by Discrete Event Systems Theory, allowing some computational modeling like the simulation, for instance.

The Lean Construction philosophy is based on the study of the processes, aiming the mitigation of the discontinuities and removing the activities which do not add value to the final product. In some situations, the managers can propose a rebuilding of the productive processes, modifying completely the original process (Koskela, 1992). Heavy civil construction, such as earthmoving and paving services, is a prominent area for application of lean concepts.

Regarding the discrete event simulation in earthmoving projects, several works have been reported in the literature. Several simulation approaches are presented by Jayawardane \& Price (1994a, 1994b), Marzouk and Moselhi (2000), Marzouk (2002), Alkass et al. (2003), Yang et al. (2003), Bargstädt \& Blickling (2005), Moselhi \& Alshibani (2007), Prata et al. (2008), Zhang (2008) and Cheng et al. (2011). Concerning the application of simulation models for implementing lean concepts, some papers have been reported in the literature: Tommelein (1998), Al-Sudairi et al. (1999), Halpin \& Kueckmann (2002), Farrar et al. (2004), Hosseini et al. (2012) and Hosseini et al. (2014).

Although the literature on earthmoving simulation is vast, the proposition of models for implementation of lean concepts in earthmoving and paving is very limited. Farrar et al. (2004) was the only study in the specialized literature to approach the implementation of Lean Construction philosophy in earthmoving and paving services. These authors do not consider the construction costs, only the activities durations. In addition, such authors consider a variable productivity that is measured through the simulations.

This paper aims at presenting discrete event simulation models for implementation of Lean Construction concepts in earthmoving and paving services, in an integrated model.

Three simulation models were proposed: one without lean concepts and two applying lean concepts. The models consider the following activities: earthmoving, sub-base, base and asphalt surfacing. The proposed models in this paper consider: (i) a fixed productivity that is taken from a service cost elaboration; (ii) construction costs; and (iii) construction duration. Real data was gathered, enabling the validation of the proposed approaches as well as the comparison between the real system and the suggested operational policies.

\section{PROBLEM DESCRIPTION}

Earthmoving and paving activities consist in a promising area for the application of Lean Production concepts because these operations are related with movement and handling of large amounts of materials, using a great quantity of expensive resources (Mitoso, 2007). The application of the Lean Philosophy in heavy civil construction can avoid several problems such as losses of materials, reworks and the rates of equipment inactivity.

The problem under study consists in the development of a methodology which allows the testing of the implementation of Lean Production policies in earthmoving and paving services, aiming the quantification of the impacts of these practices. In the Figure 1, one can observe the operations considered in the modeling process.

The proposed models are composed of four blocks of activities, considered in a sequential manner: Earthmoving, Sub-base, Base and Asphalt Surfacing. For the development of the discrete event simulation model for earthworks, it was used the software Simul8 (Hauge e Paige (2004), Chwif et al. (2015)), which is a well-known simulator in the corporate business. With the Simul8, one can obtain several performance indicators of the modeled system, such as cycle 
times, equipment utilization rates, resource utilization rates and queues formation, among others.

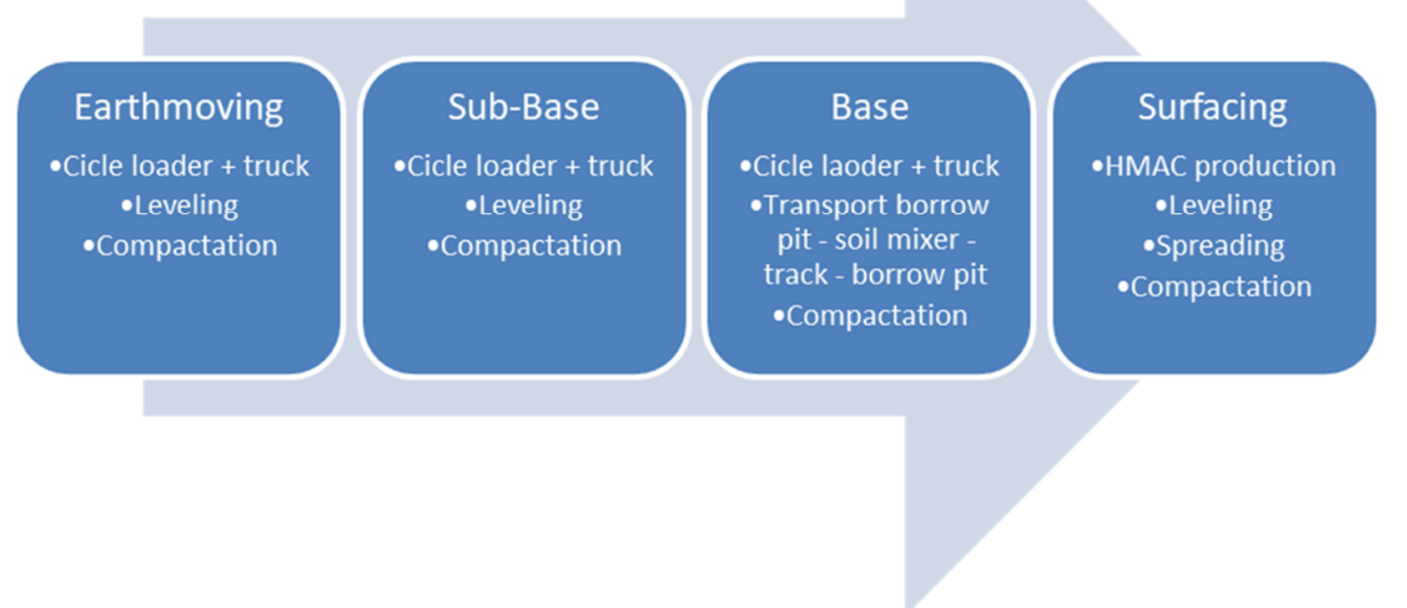

Figure 1. General scheme of the modeled activities

\section{METHODOLOGY}

In this work, three models are proposed: one modeled the reality and the others consider lean concepts. In the first model (named Model 1), the lean concepts are not considered. In this model, does not occur the overlapping of the activities, that is, the operations are performed in a sequential manner. For example, the sub-base operations start after the end of the earthmoving operations, and so on.

In the second model (named Model 2), some operations are considered with overlapping, facilitating the execution of the activities as well as maximizing the utilization of the loaders and reducing the idleness of the dump trucks.

In the third model, it was proposed a new scheduling for the execution of the base layer. In the proposed schedule, the base operations are performed concomitantly with the earthmoving and sub-base operations. Thus, it is needed a second work front, increasing the amount of equipment, but reducing substantially the constructions total duration.

\subsection{Lean concepts adopted in the models}

Aiming to verify the efficiency improvement of earthmoving and paving services, in comparison with the current operation of these systems, some strategies were implemented in the proposed models. The Lean Construction concepts utilized in the modeling are described as follow:

a) Specify value: value can be viewed by the difference between the benefits and costs of a given process. The value of the processes needs to be specified, aiming their further optimization.

b) Map the value stream: This mapping consists in the determination of all the steps performed in the value stream, removing, whenever feasible, those steps that do not add value. 
c) Make value flow: This concept consists in the making the value-addition steps arise in narrow sequence so the goods will flow smoothly in the process.

d) Pull value: The activities must pull value from the next step in the process.

In the Figures 2 and 3, the lean concepts adopted in the Models 2 and 3, which are based in the conceptual framework of Lean Production Theory proposed by Al-Sudairi et al. (1999) are illustrated.

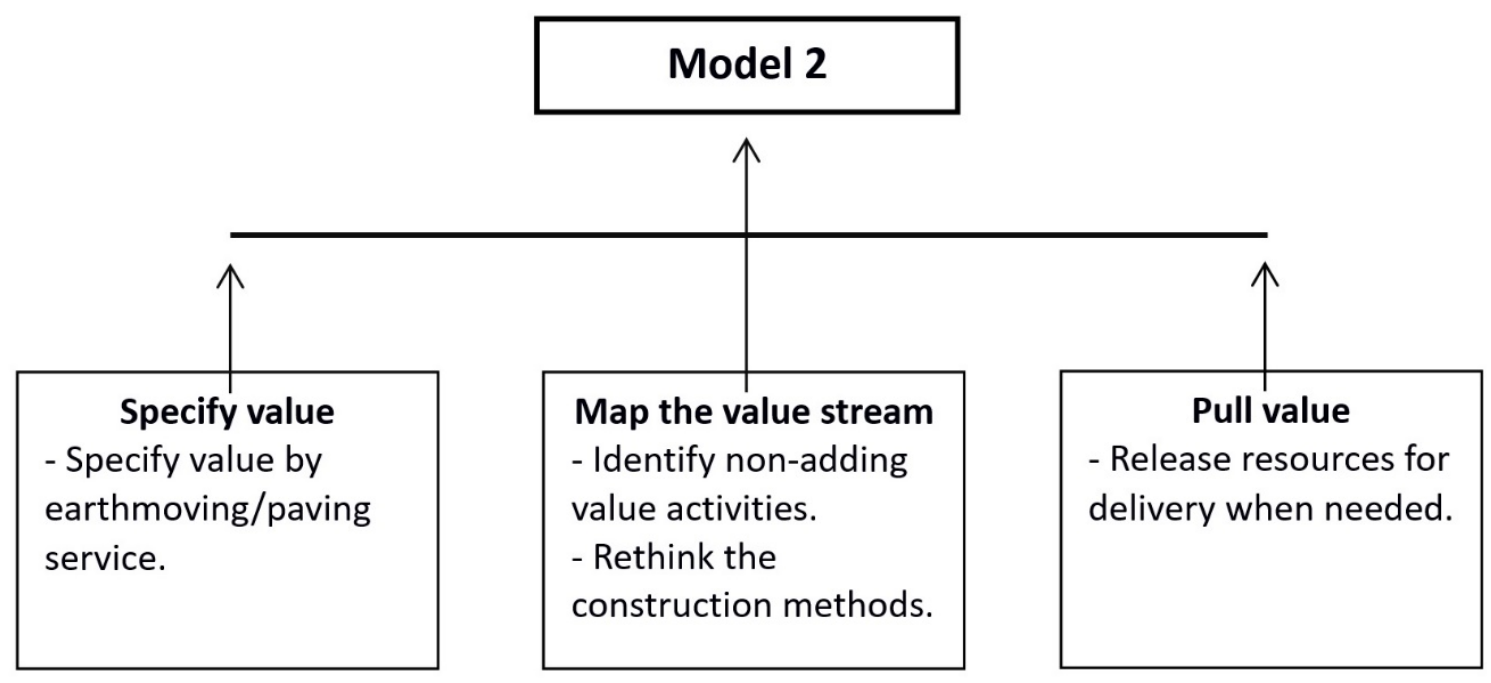

Figure 2. Lean concepts considered in the Model 2

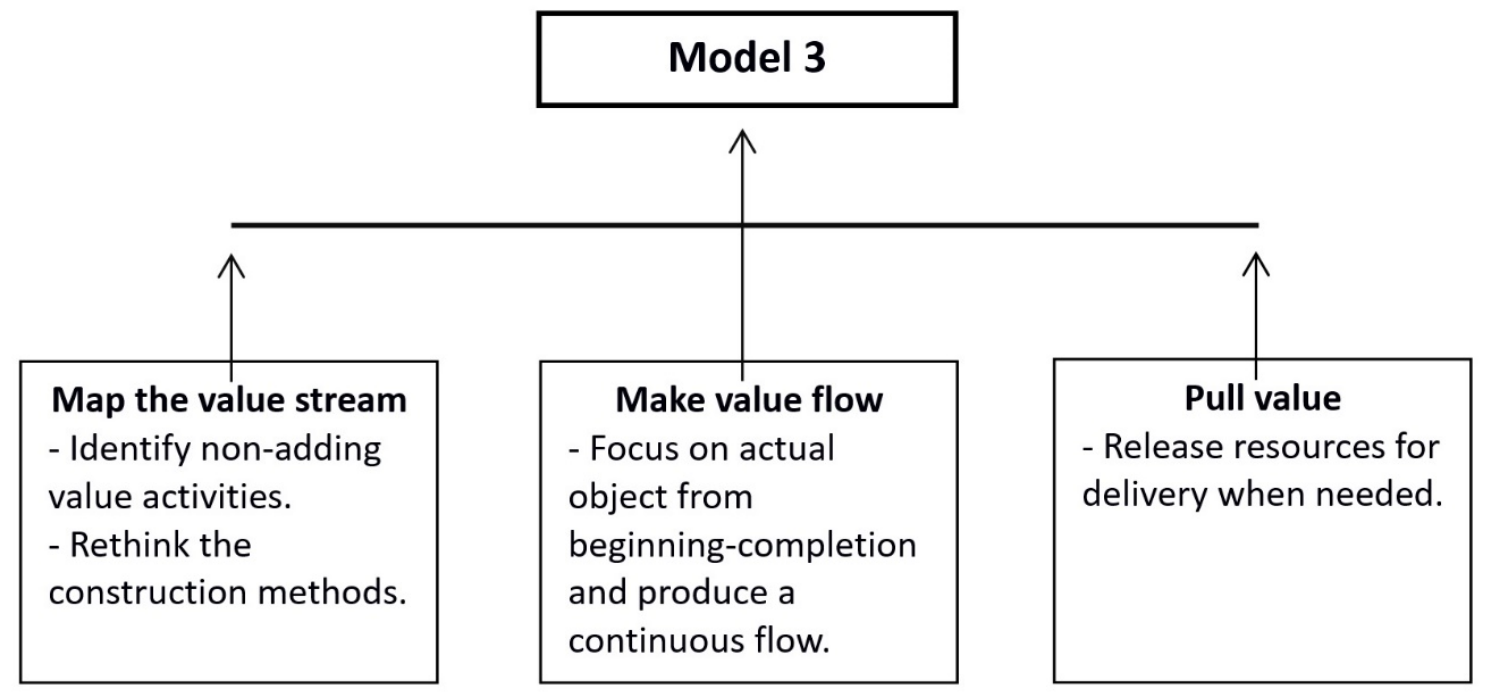

Figure 3. Lean concepts considered in the Model 3

\subsection{Activities considered in the models}

The developed models have four distinct and independent blocks of activities, which can be optimized in relation to the equipment fleet and the simultaneity of operations. The first block represents the earthmoving activities, considering cut, fill, hauling and compaction, in the analyzed area. The second represents the sub-base operations, in which are modeled cut, fill, hauling, compaction and leveling. The above mentioned processes are illustrated in Figure 4. 


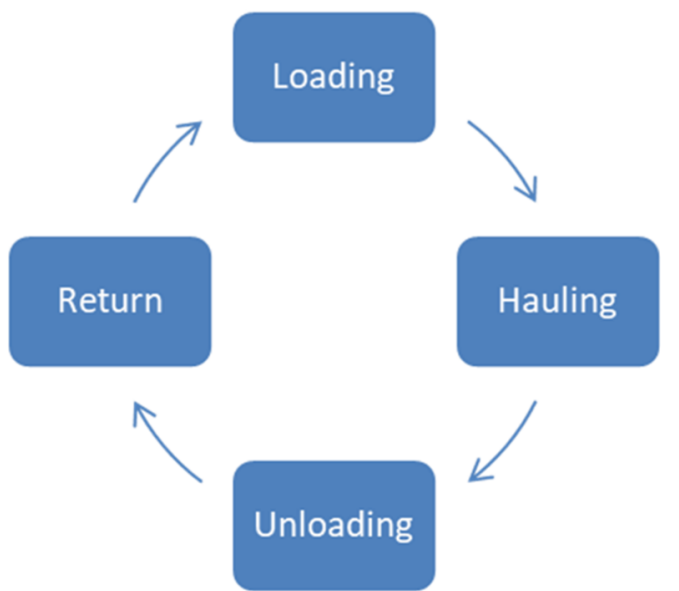

Figure 4. Simplified cycle for Earthmoving and Sub-base

In the third block of the model, are represented the inherent operations to the pavement base. In the proposed models, the base is a sand-gravel mix composed of $70 \%$ of soil and $30 \%$ of gravel. Therefore, the model considers the haulage of materials from the borrow pits to the soil mixers, in which is assumed that a third-party company has transported the rocks. After the crushing and mixing of the materials, the stabilized soil is transported to the centroid of the considered section, where the material is unloaded and compacted. The base process is illustrated in the Figure 5.

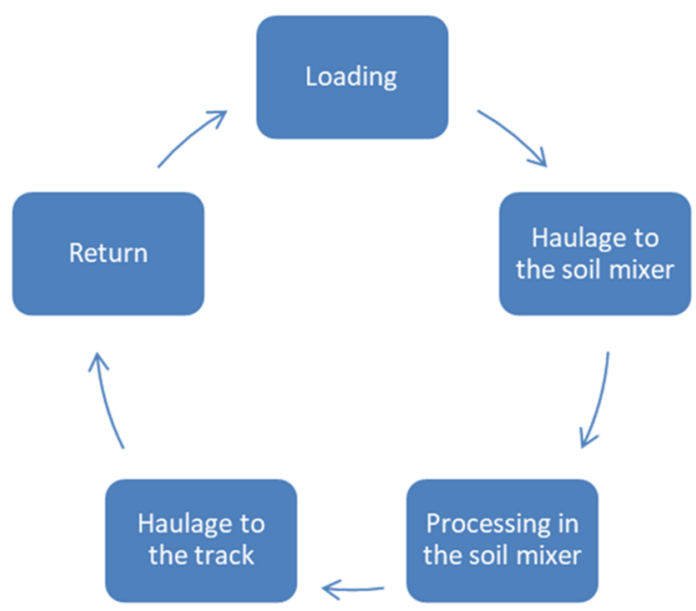

Figure 5. Simplified cycle for Base

Finally, the last block of the simulation model consists in the application of a layer of Hot Mix Asphalt (HMA), with a thickness of $5 \mathrm{~cm}$. Subsequently is performed the spreading, finishing and compacting of the layer. It can be observed that the HMA production is admitted as performed by a third-party company, being the material received on the track. The asphalt surfacing process is illustrated in the Figure 6.

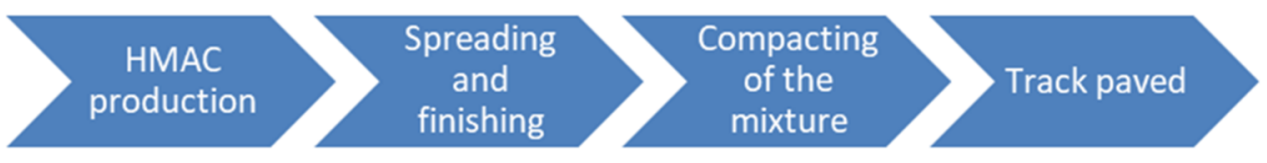

Figure 6. Simplified cycle for asphalt surfacing 


\subsection{Proposed simulation models}

The above mentioned subsystems were modeled in the Simul8, an important discrete event simulator in the engineering sector. Simul8 has a graphical interface that enables the user to construct models in a simple way. The processes of data input analysis, as well as of simulation analysis are facilitated by the robust interface of Simul8.

The earthmoving process is illustrated in the Figure 7. In this model, the backhoe -dump truck cycle is represented like a discrete event system, with this dynamic nature. Firstly, the backhoe gets material in an embankment and loads the dump truck while its capacity is available. After that, the dump truck performs the transportation of the materials to the fill, performing the unloading operation. In addition, the operations of leveling and compaction are performed for the conclusion of earthmoving process.

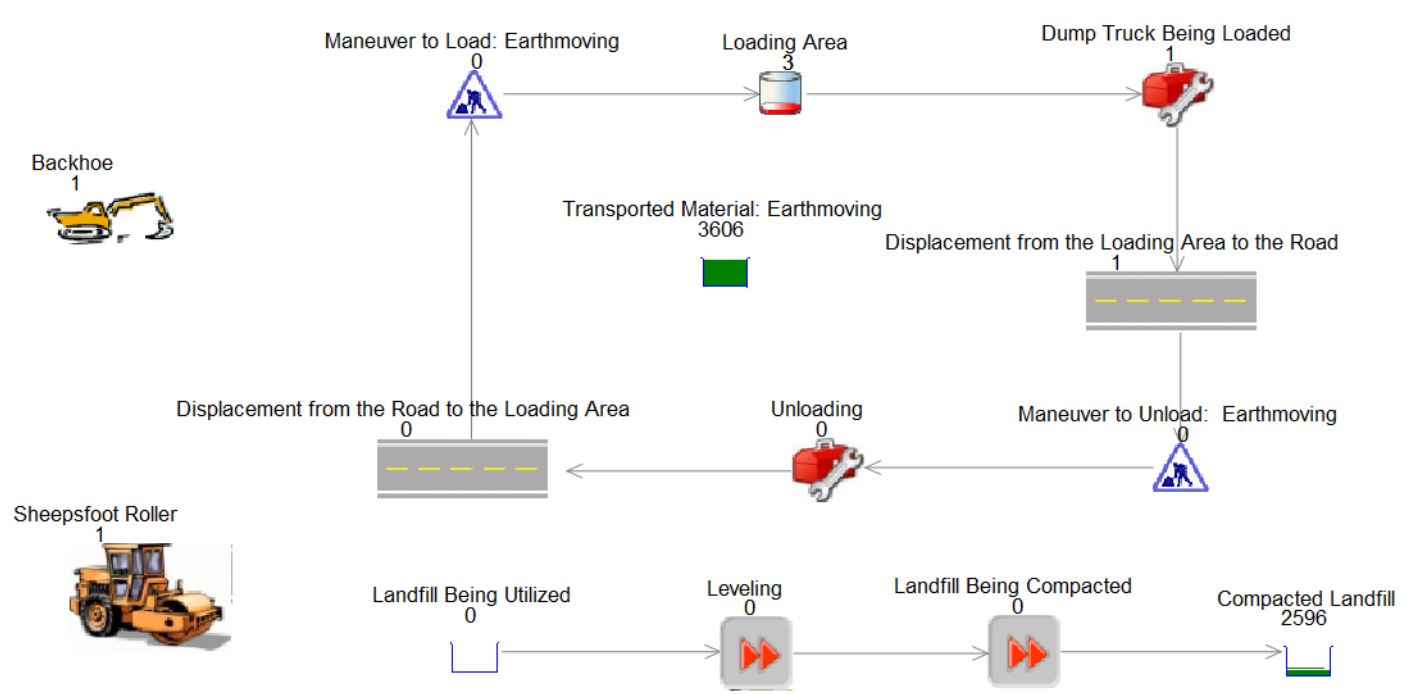

Figure 7. Earthmoving model in Simul8

The sub-base process is illustrated in the Figure 8. In general terms, the sub-base process is roughly equal to the earthmoving process. The key distinction between them is that in the subbase process, the materials must have rolling resistance characteristics, which is not the case with earthmoving process.

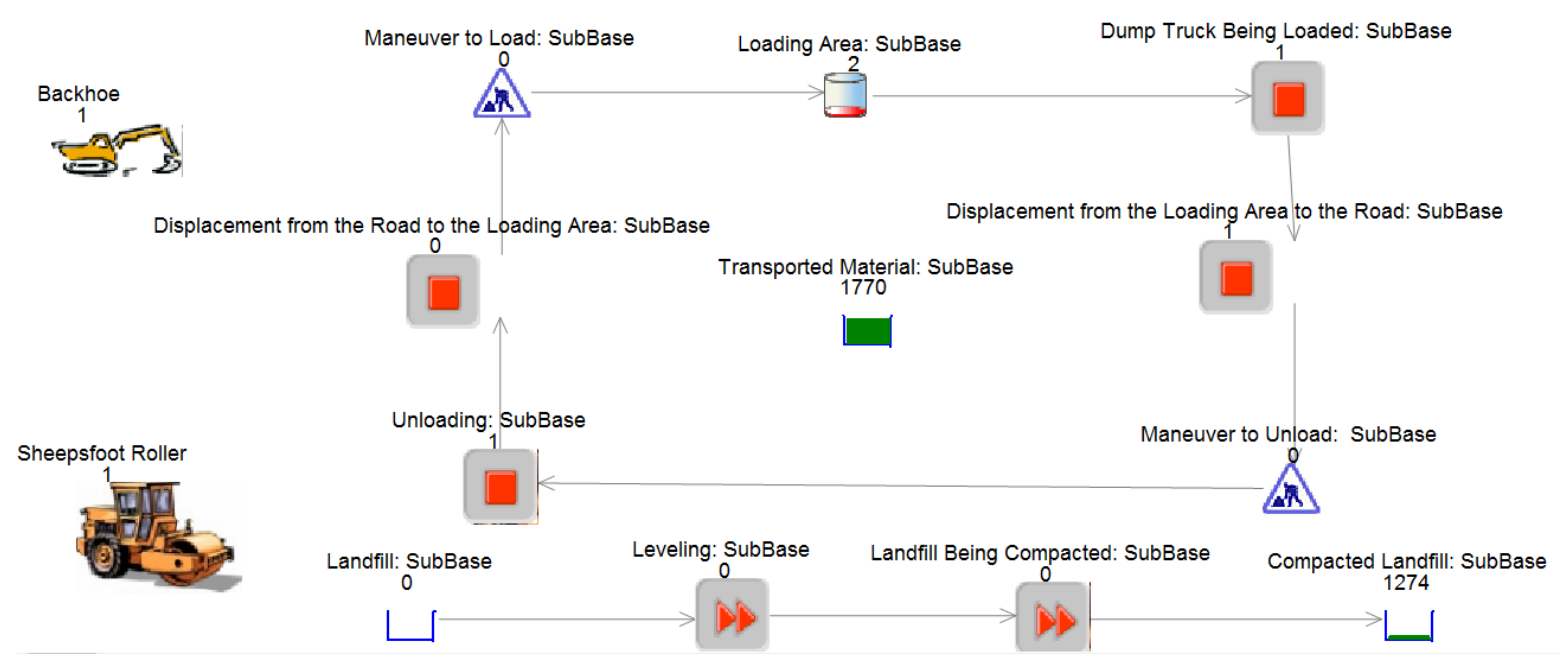

Figure 8. Sub-base model in Simul8 
The base process is illustrated in the Figure 9. In the proposed model is considered the following combination of parameters: the base is composed by 70 per cent gravel and 30 per cent soil. The dump truck transports the material from deposit to the soil mixer. It is considered that the outsourced company has already delivered the stones. After stone crushing, the soil is stabilized, deposited, distributed and compacted.

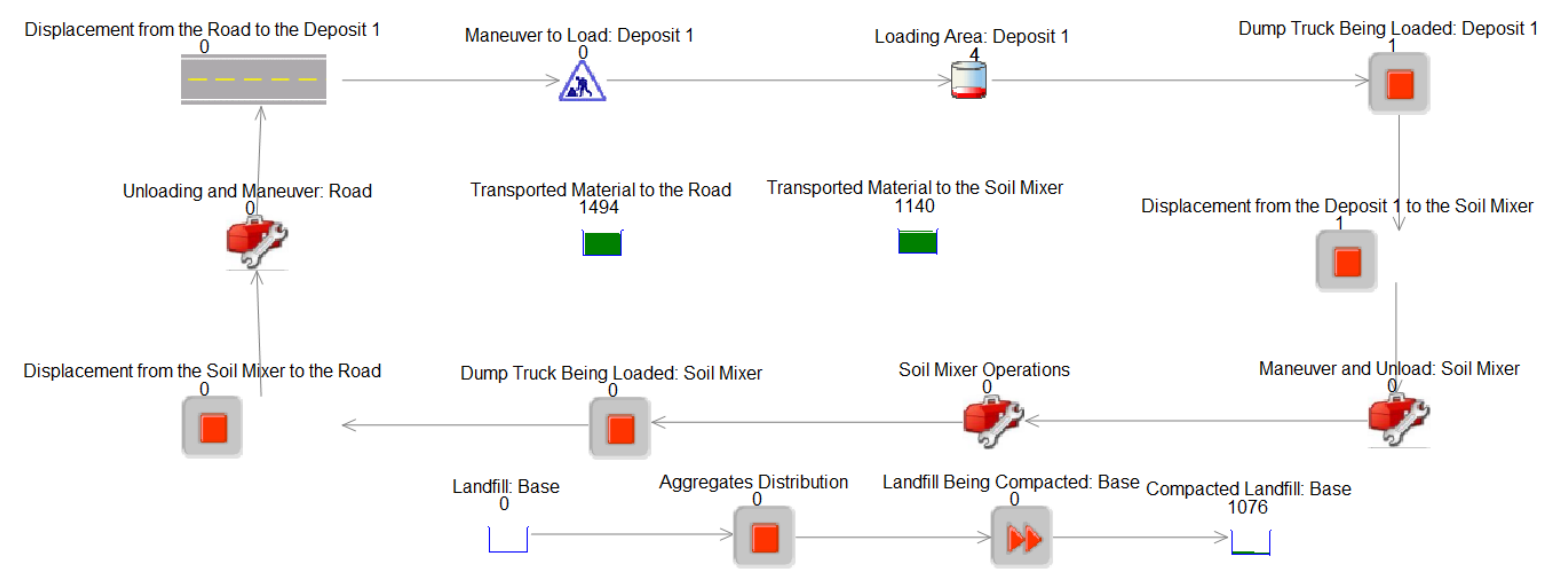

Figure 9. Base model in Simul8

Finally, the last stage of the simulation is the asphalt surfacing model, as illustrated in the Figure 10. In this subsystem, the activities are performed in a linear way for the application of HMA, with a thickness of $5 \mathrm{~cm}$. Firstly, the HMA is produced. It is important to observe that in present model this production is considered outsourced and the material is received in the track. After, the HMA is spread and finished. Finally, the mixture receives the final compaction.

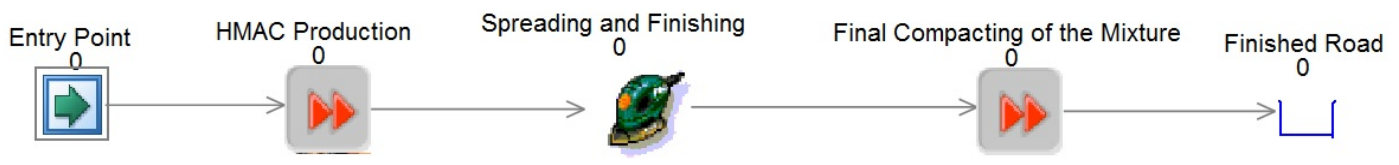

Figure 10. Asphalt surfacing model in Simul8

For the verification of the benefits of the proposed approach in comparison with the real operation, it was proposed a cost function, which was based on the cycle time obtained by the simulation model. The unit costs of earthmoving and paving services are multiplied by the cycle time, giving the cost of each scenario. Having the costs of the proposed scenarios, one can compare the benefits of the lean strategies with the current operation of the modeled system.

\section{CASE STUDY}

Aiming to perform a validation of the developed model as well as measure the benefits of the proposed approach, real data was gathered form a real case. The case study is related to a highway construction, located in the Northeast region of Brazil, with a total extension of 32,1 Km.

For the paving execution, it was considered a sub-base with natural material of borrow pits near the track. In the base execution, it was used material from a borrow pit located $6.6 \mathrm{~km}$ away from the axis of the track, with a mixture of $30 \%$ of gravel. The execution of the mixture must be performed in a soil mixer. The pavement layers have the following thickness: surface of $5 \mathrm{~cm}$ (HMA), base of $15 \mathrm{~cm}$ and sub-base of $20 \mathrm{~cm}$. The main data used in the modeling is presented in the Table 1. 
Table 1: Main volumes and distances adopted in the models

\begin{tabular}{l|l}
\hline Project data & Adopted value \\
\hline Volume of materials (earthmoving) & $3.602 \mathrm{~m}^{3}$ \\
Volume of materials (sub-base) & $1770,42 \mathrm{~m}^{3}$ \\
Volume of materials (base) & $1.142 \mathrm{~m}^{3}$ \\
Volume of HMA (paving) & $209,86 \mathrm{~m}^{3}$ \\
Average transportation distance (earthmoving) & $4,63 \mathrm{~km}$ \\
Distance between the borrow pit and the soil mixer & $17,06 \mathrm{~km}$ \\
Distance between the soil mixer and the track & $6,65 \mathrm{~km}$
\end{tabular}

In these simulations, some assumptions were made. Taking into consideration that the activity of processing the materials in the soil mixer is continuous, the first assumption is that at the moment a truck needs to be loaded, the material is available. The production of HMA is considered continuous for the same reason, therefore the second assumption is that the HMA is always available for a given truck. The third assumption is regarding the loaders. It is considered that the loaders are governing the production, in order to verify if there is the queues formation of the trucks.

Aiming to evaluate the system performance, we proposed six indicators, which are described as follows:

a) Total cost $(\mathrm{R} \$)$ : total cost for earthmoving and paving services.

b) Total time (days): total work time required for the execution of earthmoving and paving services;

c) $T_{1}$ : minimum wait time in the queues;

d) $T_{2}$ : average wait time in the queues;

e) $T_{3}$ : maximum wait time in the queues.

f) Total time (h): total time for the execution of surfacing services. It can be observed that $\mathrm{U} \$ 1,00$ is approximately $\mathrm{R} \$ 2,20$ (base-year 2014).

After the development of the model for the current system, were applied some concepts of lean construction, such as process optimization and minimization of the set-up activities. The initial model has performed the activities in a linear manner, so that the block of activities for the fill compaction only could be started when the transport of materials have been finished. Similarly, the block of activities of transport of sub-base materials only could be started when the fill compaction has been finished and so on.

The simultaneity of the activities was modeled in the following manner: the block of activities for the sub-base systems only can begin when the earthmoving block is finished. In the model, it was enabled that subsequent activities can be performed in parallel when a given percentage value of the predecessor activity was performed. Reducing these delays between the activities, the cycle time could be reduced with the maintenance of the same pool of machines.

In the Table 2 and 3 are presented the minimum, average and maximal waiting times for the dump trucks in the queues, as well as the duration of each stage considered in the modeled processes, in the models 2 and 3, respectively. The models were run 20 times for the obtaining of the presented results. The main difference between models 2 and 3 consists in the fact that in the model 3 the base activity was divided into two independent parts. Therefore, it is possible the execution of a part of the base concomitantly with other processes, reducing the total execution time. 
Table 2: Waiting times in the queues obtained by the Model 2

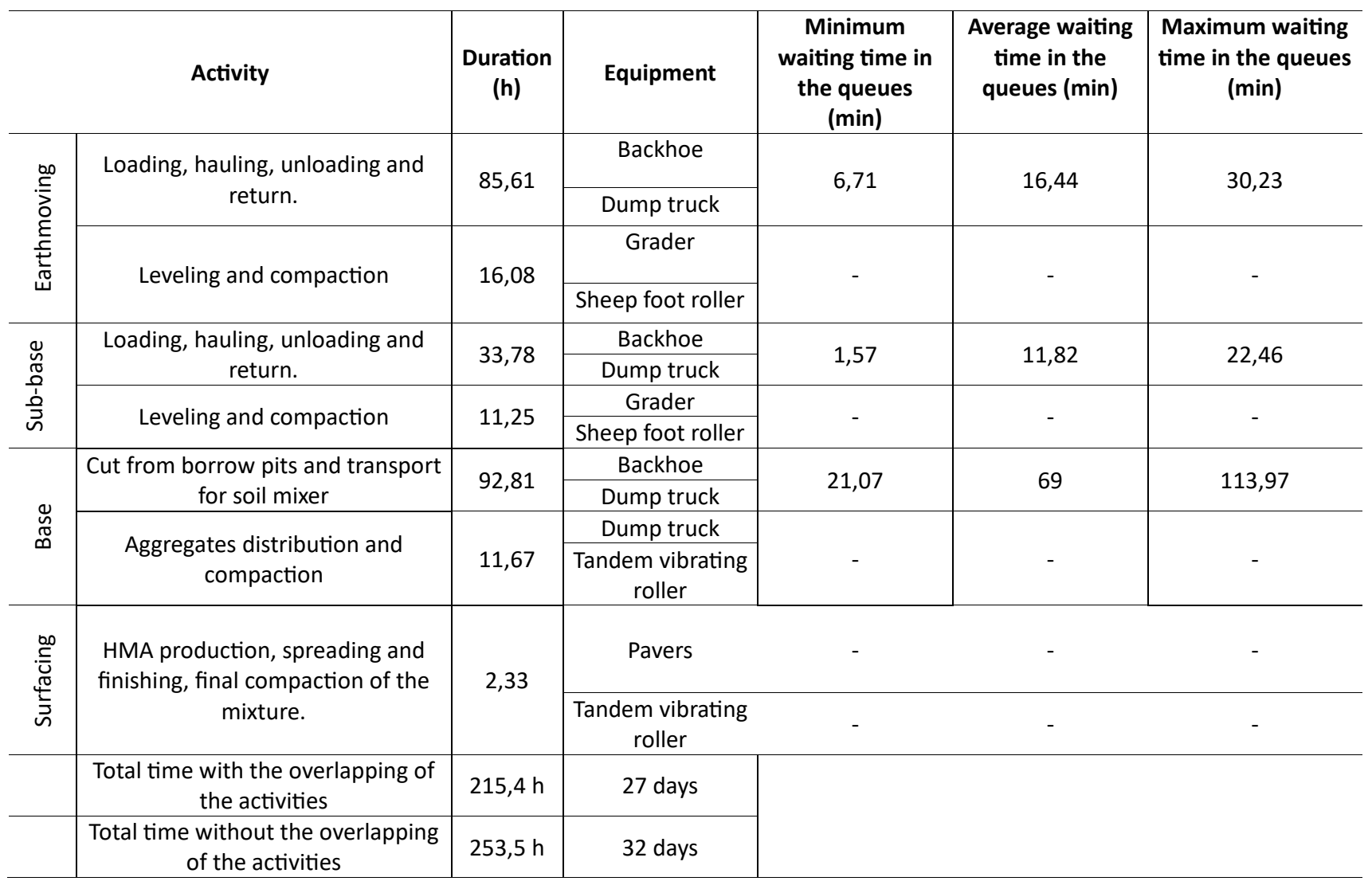

Table 3: Waiting times in the queues obtained by the Model 3

\begin{tabular}{|c|c|c|c|c|c|c|}
\hline \multicolumn{2}{|r|}{ Activity } & \multirow{3}{*}{$\begin{array}{c}\begin{array}{c}\text { Duration } \\
\text { (h) }\end{array} \\
85,61\end{array}$} & \multirow{3}{*}{$\begin{array}{c}\text { Equipment } \\
\text { Backhoe }\end{array}$} & \multirow{3}{*}{$\begin{array}{c}\text { Minimum } \\
\text { waiting time in } \\
\text { the queues } \\
\text { (min) }\end{array}$} & \multirow{3}{*}{$\begin{array}{c}\text { Average waiting } \\
\text { time in the } \\
\text { queues (min) } \\
16,44\end{array}$} & \multirow{3}{*}{$\begin{array}{c}\text { Maximum waiting } \\
\text { time in the queues } \\
\text { ( } \mathbf{m i n} \text { ) }\end{array}$} \\
\hline \multirow{4}{*}{ 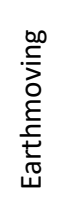 } & \multirow{2}{*}{$\begin{array}{l}\text { Loading, hauling, unloading and } \\
\text { return. }\end{array}$} & & & & & \\
\hline & & & & & & \\
\hline & \multirow{2}{*}{ Leveling and compaction } & \multirow{2}{*}{16,08} & Grader & \multirow{2}{*}{ - } & \multirow{2}{*}{ - } & \multirow{2}{*}{ - } \\
\hline & & & Sheep foot roller & & & \\
\hline \multirow{4}{*}{ 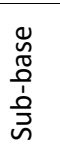 } & \multirow{2}{*}{$\begin{array}{l}\text { Loading, hauling, unloading and } \\
\text { return. }\end{array}$} & \multirow{2}{*}{33,78} & Backhoe & \multirow{2}{*}{1,57} & \multirow{2}{*}{11,82} & \multirow{2}{*}{22,46} \\
\hline & & & Dump truck & & & \\
\hline & \multirow{2}{*}{ Leveling and compaction } & \multirow{2}{*}{11,25} & Grader & \multirow{2}{*}{-} & \multirow{2}{*}{ - } & \multirow[b]{2}{*}{ - } \\
\hline & & & Sheep foot roller & & & \\
\hline \multirow{5}{*}{ 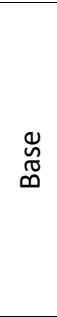 } & \multirow{2}{*}{$\begin{array}{c}\text { Cut from borrow pits and transport } \\
\text { for soil mixer }\end{array}$} & \multirow{2}{*}{93,03} & Backhoe & \multirow{2}{*}{21,07} & \multirow{2}{*}{69} & \multirow{2}{*}{113,97} \\
\hline & & & Dump truck & & & \\
\hline & $\begin{array}{l}\text { Load in soil mixer, transport and } \\
\text { unload }\end{array}$ & 49,70 & Dump truck & 0,7 & 15,29 & 30,58 \\
\hline & \multirow[b]{2}{*}{$\begin{array}{l}\text { Aggregates distribution and } \\
\text { compaction }\end{array}$} & \multirow[b]{2}{*}{11,67} & Dump truck & \multirow[b]{2}{*}{-} & \multirow[b]{2}{*}{-} & \multirow[b]{2}{*}{ - } \\
\hline & & & $\begin{array}{c}\text { Tandem vibrating } \\
\text { roller }\end{array}$ & & & \\
\hline \multirow{4}{*}{ 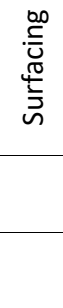 } & \multirow{2}{*}{$\begin{array}{l}\text { HMA production, spreading and } \\
\text { finishing, final compaction of the } \\
\text { mixture. }\end{array}$} & & Pavers & - & - & - \\
\hline & & נכנ,2 & $\begin{array}{l}\text { Tandem vibrating } \\
\text { roller }\end{array}$ & - & - & - \\
\hline & $\begin{array}{c}\text { Total time with the overlapping of } \\
\text { the activities }\end{array}$ & $137,7 \mathrm{~h}$ & 22 days & & & \\
\hline & $\begin{array}{c}\text { Total time without the overlapping } \\
\text { of the activities }\end{array}$ & $303,5 \mathrm{~h}$ & 38 days & & & \\
\hline
\end{tabular}


The simulation results are presented in Table 4. Analyzing the above mentioned results, one can observe that there is a clear advantage in the employment of rationalization tools, such as the lean concepts, in earthmoving and paving services.

Table 4: Simulation results

\begin{tabular}{|c|c|c|c|c|c|c|c|c|}
\hline & Model 1 & Model 2 & Model 3 & $\Delta$ Model 2 (RS) & $\Delta$ Model 3 (RS) & $\Delta$ Model 2 (\%) & $\Delta$ Model $3(\%)$ \\
\hline \multicolumn{2}{|c|}{ Total cost (R\$) } & $359.127,84$ & $257.621,78$ & $277.445,47$ & $101.506,07$ & $-81.682,37$ & $-28,3$ & $-22,7$ \\
\hline \multicolumn{2}{|c|}{ Total time (days) } & 32,0 & 27,0 & 22,0 & $-5,0$ & $-10,0$ & $-15,6$ & $-31,3$ \\
\hline \multirow{3}{*}{ 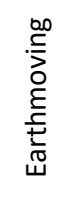 } & $T_{1}(\mathrm{~h})$ & 25,71 & 6,71 & 6,71 & -19 & -19 & $-73,9$ & $-73,9$ \\
\hline & $T_{2}(\mathrm{~h})$ & 42,28 & 16,44 & 16,44 & $-25,84$ & $-25,84$ & $-61,1$ & $-61,1$ \\
\hline & $T_{3}(\mathrm{~h})$ & 59,81 & 30,23 & 30,23 & $-29,58$ & $-29,58$ & $-49,5$ & $-49,5$ \\
\hline \multirow{3}{*}{ 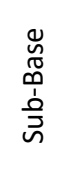 } & $T_{1}(\mathrm{~h})$ & 19,71 & 1,57 & 1,57 & $-18,14$ & $-18,14$ & $-92,0$ & $-92,0$ \\
\hline & $T_{2}(\mathrm{~h})$ & 32,77 & 11,82 & 11,82 & $-20,95$ & $-20,95$ & $-63,9$ & 63,9 \\
\hline & $T_{3}(\mathrm{~h})$ & 44,76 & 22,46 & 22,46 & $-22,3$ & $-22,3$ & $-49,8$ & $-49,8$ \\
\hline \multirow{3}{*}{ 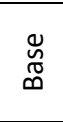 } & $T_{1}(\mathrm{~h})$ & 45,93 & 21,07 & 21,07 & $-24,86$ & $-24,86$ & $-54,1$ & $-54,1$ \\
\hline & $T_{2}(\mathrm{~h})$ & 124,23 & 69 & 69 & $-55,23$ & $-55,23$ & $-44,5$ & $-44,5$ \\
\hline & $T_{3}(\mathrm{~h})$ & 191,84 & 113,97 & 113,97 & $-77,87$ & $-77,87$ & $-40,6$ & $-40,6$ \\
\hline 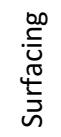 & $\begin{array}{c}\text { Total } \\
\text { time (h) }\end{array}$ & 2,33 & 2,33 & 2,33 & 0,0 & 0,0 & 0,0 & 0,0 \\
\hline
\end{tabular}

Taking into account the results obtained in the simulations, it should be highlighted the differences between the Model 1 (without lean concepts) and the Models 2 and 3 (with lean concepts). The Model 2 presented a reduction of $15.6 \%$ in the construction execution time and a reduction of $28.3 \%$ in the total cost, in comparison with the Model 1 . The Model 3 presented reduction of $31.3 \%$ in the construction execution time and a reduction of $22.7 \%$ in the total cost, in comparison with the Model 1.

Regarding the asphalt surfacing, one can observe that the Models 2 and 3 do not incur in improvement in terms of construction times. This is due to the fact that this process is essentially sequential, as well as the fact that the production of HMA was not modeled. Thus, there are no inefficiencies that could be mitigated by the lean concepts.

It is clear that the proposed approach is a powerful decision support tool, being valuable for the planners in the decision-making process. With the discrete event models proposed, several scenarios and operational policies can be previously tested, enabling the decision makers to develop efficient strategies for the earthmoving and paving activities.

\section{CONCLUSIONS}

The simulation model described in this paper is a powerful technique for planning the operations of earthmoving and paving services, enabling the implementation of lean concepts in the productive processes. The proposed model allows the obtaining of rationalized operational policies, incurring in reductions of cycle times, equipment utilization rates, resource utilization rates and queues formation, among others performance indicators.

It can be highlighted that, although the proposed approach enables operational strategies 
with cost reductions, these cost values does not represent the real cost of the construction, because they do not consider the labor costs. In the applied unit costs for each service, only the equipment costs are considered.

It is worthy of note that the stretch adopted in the case study is an almost plain terrain, with little variation in the cross section. Another feature of the case study is regarding the distance between the analyzed stretch and the borrow pits and soil mixer, which are virtually identical. This means that the obtained results are specific for this situation. There is no guarantee that other topographical or geotechnical features can lead to reductions of this same magnitude or lead to reductions at all. Each situation needs to be modeled and simulated.

A limitation of the study is the lack of real data on the performed operational times in the studied construction. Without these data, the authors were not able to validate statistically the proposed model. However, according to authors' experience, the proposed model reflects well the real system.

In the proposed modeling, could be simulated different locations and sizes of the soil mixer, as well as different cutting places for base depending of the section of the road. Other services necessary for the highway construction, such as drainage, special artworks and horizontal road markings, enabling a better evaluation of the improvements obtained by the lean concepts application.

In the proposed approach, there is no consideration of quality and safety when comparing the lean and non-lean models. Other performance indicators which reflect these aspects need to be developed and embedded in the simulation model.

As a further development of the work presented in this paper, the authors are currently working in the integration of discrete event simulation models and mixed integer programming models, aiming the evaluation of the lean policies integrated with the optimal distribution of materials, as well as in the extension of the proposed approach in drainage and maintenance services. In addition, the consideration of tank truck and aerator for correcting the soil moisture, the application of asphalt priming on base and sub-base, as well as the consideration of climatic aspects could be added in the proposed model.

\section{ACKNOWLEDGEMENTS}

The support of the National Council for Scientific and Technological Development (CNPq) is acknowledged and appreciated.

\section{REFERENCES}

Al-Sudairi, A. A.; H. M. Brown; J. E. Diekmann; A. D. Songer (1999) Simulation of Construction Processes: Traditional Practices versus Lean Principles. Proceedings IGLC-7.

Alkass, S.; K. El-Moslmani; M. AlHussein (2003) A Computer Model for Selecting Equipment for Earthmoving Operations Using Queuing Theory. CIB REPORT, vol. 284, 1- 7.

Bargstädt, H. J. e A. Blickling (2005) Implementation of Logic for Earthmoving Processes with a Game Development Engine.

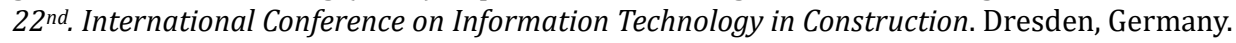

Cheng, F.F.; Y.W. Wang; X.Z. Zing e Y. Bai (2011) A Petri net simulation model for virtual construction of earthmoving operations. Automation in Construction, v. 20, N. 2, p. 181-188. DOI: 10.1016/j.autcon.2010.09.015.

Chwif, L.; A. C. Medina; W. I. Pereira; D. R. Vieira e J. E. Pécora Jr (2015) Introdução ao Simul8: um guia prático. São Paulo: Ed. dos Autores. Disponível em: <http://livrosimulacao.eng.br/introducao-ao-simul8-download-gratuito/>. Acesso em $<05$ nov 2017>.

Farrar, J. M; S. M. Abourizk; X. Mao (2004) Generic Implementation of Lean Concepts in Simulation Models. Lean Construction Journal, vol. 1, n. 1, p. 1-23.

Halpin, D. W.; M. Kueckmann (2002) Lean Construction and Simulation. Proceedings of the 2002 Winter Simulation Conference. DOI: 10.1109/WSC.2002.1166453.

Hauge, J. W. e K. N. Paige (2004) Learning SIMUL8: The Complete Guide. Plain Vu Publishers; 2nd edition. 1013 p. Boston. 
Hosseini, S.A.A.; A. Nikakhtar e P. Ghoddousi (2012) Flow production of construction processes through implementing lean construction principles and simulations. International Journal of Engineering and Technology, vol. 4, n. 4, p. 475-479. DOI: 10.7763/ijet.2012.v4.414.

Hosseini, S.A.A.; A. Nikakhtar e P. Ghoddousi (2014) Verification of Lean Construction benefits through simulation modeling: a case study of bricklaying process. KSCE Journal of Civil Engineering, vol. 18, n.5, p. 1248-1260. DOI: 10.1007/s12205-0140305-9.

Jayawardane, A. K. W. e A. D. F. Price (1994a) A new approach for optimizing earth moving operations - Part I. Proceedings of Institution of Civil Engineers - Transport, v. 105, n. 8, p. 195-207.

Jayawardane, A. K. W. e A. D. F. Price (1994b) A new approach for optimizing earth moving operations - Part II. Proceedings of Institution of Civil Engineers - Transport, v. 105, n. 9, p. 249-258. DOI: 10.1680/itran.1994.27136.

Koskela, L. (1992) Application of the New Production Philosophy to Construction. Technical Report 72, CIFE, Stanford University, Stanford.

Marzouk, M. e O. Moselhi (2000) Optimizing earthmoving operation using object-oriented simulation. Proceedings of the 2000 Winter Simulation Conference, Orlando.

Marzouk, M. (2002) Optimizing Earthmoving Operations Using Computer Simulation. Department of Building, Civil and Environmental Engineering, Concordia University, Montreal. DOI: 10.1109/wsc.2000.899188.

Moselhi, O. e A. Alshibani (2007) Crew optimization in planning and control of earthmoving operation using spatial technologies. Journal of Information Technology in Construction - ITcon, v. 12, p. 121 - 137.

Prata, B. A.; E. F. Nobre Jr; G. C. Barroso (2008) A stochastic colored petri net model to allocate equipments for earth moving operations. Journal of Information Technology in Construction, v. 13, p. 476-490.

Tommelein, I.D. (1998) Pull-driven scheduling for pipe-spool installation simulation of a lean construction technique. Journal of Construction Engineering and Management, v. 124, n. 4, p. 279-288. DOI: 10.1061/(asce)0733-9364(1998)124:4(279).

Yang, J.; D. J. Edwardsa; P. E.D. Loveb (2003) A computational intelligent fuzzy model approach for excavator cycle time simulation. Automation in Construction, v. 12, p. 725-735. DOI: 10.1016/s0926-5805(03)00056-6.

Zhang, H. (2008) Multi-objective simulation-optimization for earthmoving operations. Automation in Construction, v. 18, p. 79-86. DOI: 10.1016/j.autcon.2008.05.002. 